\title{
The effect of organic and conventional production methods on sea bream growth, health and body composition: a field experiment
}

\author{
ELENI MENTE ${ }^{1,2}$, ALEXANDROS STRATAKOS ${ }^{1}$, IOANNIS S. BOZIARIS ${ }^{1}$, \\ KONSTANTINOS A. KORMAS ${ }^{1}$, VASILEIOS KARALAZOS ${ }^{1}$, \\ IOANNIS T. KARAPANAGIOTIDIS ${ }^{1}$, VASSILIKI A. CATSIKI ${ }^{3}$ \\ and LEONDIOS LEONDIADIS 4 \\ ${ }^{1}$ School of Agricultural Sciences, Department of Ichthyology and Aquatic Environment, University of Thessaly, Fytoko \\ Street, GR-38446 N. Ionia Magnisias, Greece.E-mail: emente@uth.gr \\ ${ }^{2}$ School of Biological Sciences (Zoology), University of Aberdeen, Tillydrone Avenue, Aberdeen, AB24 2TZ, UK. \\ ${ }^{3}$ Hellenic Centre for Marine Research, Mavro Lithari, Anavyssos, 19013, Greece. \\ ${ }^{4}$ National Centre for Scientific Research "Demokritos", GR-153 10 Ag. Paraskevi, Athens, Greece.
}

\begin{abstract}
SUMMARY: This study aimed to develop a better understanding of organic sea bream aquaculture production in Greece, in particular its consequences for fish growth, health and body composition, and to propose and update standards for sustainable organic sea bream farming. Gilthead sea bream were kept in sea cages at densities of $4 \mathrm{~kg} \mathrm{~m}^{-3}$ (organic) and $15 \mathrm{~kg} \mathrm{~m}^{-3}$ (conventional), and were fed organically produced feed ( $45 \%$ crude protein, $14 \%$ fat) or conventional feed (46\% crude protein, $17 \%$ fat). The amino acid profile of the conventional diet, particularly the lysine content, which is one of most important dietary amino acids for sea bream, appeared to be unsatisfactory. "Organic" sea bream stored less fat content in their white muscle than the conventional sea bream. The liver lipid content was lower and the hepatosomatic index was higher for the organic sea bream. The microbiological analysis showed that both Enterobacteriaceae and Escherichia coli on the skin were below the enumeration detection limit in both the organic and conventional sea bream. Total viable counts on the skin and muscle of both the organically and conventionally cultured sea bream were approximately $3 \log \mathrm{cfu} \mathrm{g}^{-1}$, which is well below the acceptable limit $\left(7 \log \mathrm{cfu} \mathrm{g}^{-1}\right)$ for marine species. The results showed that the combination of a low stocking density and feed with a different ingredient composition but similar nutritional value resulted in similar growth rates and nutrient profiles of the final product. Further research on nutrition is required to provide information on setting the appropriate standards for organic sea bream aquaculture to ensure that the final product is in line with the consumers' preferences.
\end{abstract}

Keywords: sustainable, organic, sea bream aquaculture.

RESUMEN: EFECTO DE LOS MÉTODOS DE PRODUCCIÓN ORGÁNICA Y CONVENCIONAL EN EL CRECIMIENTO, SALUD Y COMPOSICIÓN CORPORAL DEL PARGO: UN EXPERIMENTO DE CAMPO. - Este estudio tiene por objeto desarrollar una mejor comprensión de la producción acuícola orgánica del pargo en Grecia, en particular sus consecuencias en relación al crecimiento del pez, su salud y su composición corporal, y proponer y actualizar los estándares para la cría sostenible y orgánica. Los pargos dorados fueron criados en contenedores con densidades de $4 \mathrm{~kg} \mathrm{~m}^{-3}$ (orgánico) y de $15 \mathrm{~kg} \mathrm{~m}^{-3}$ (convencional) y les fue ofrecido alimento producido orgánicamente (45\% de proteina cruda, $14 \%$ de grasa) y convencionalmente (46\% de proteina cruda, $17 \%$ de grasa). El perfil de los aminoácidos de la dieta convencional, en especial en relación al contenido en lisina, uno de los aminoácidos alimentarios más importantes para pargos, pareció ser insatisfactorio. Los pargos "orgánicos" acumularon una menor cantidad de grasa en sus músculos blancos en compración con los pargos convencionales; el contenido en lípidos del hígado es menor y el índice hepatosomático es más alto en los pargos orgánicos. Los análisis microbiológicos muestran que las Enterobacteriaceae y las Escherichia coli en la piel estaban por debajo del límite de detección tanto en los pargos orgánicos como en los convencionales. El cómputo total factible en la piel y músculos de los pargos cultivados orgánica y convencionalmente fue de aproximadamente $3 \log$ ufc $\mathrm{g}^{-1}$, lo cual está por debajo del límite aceptable $\left(7 \log\right.$ ufc $\left.\mathrm{g}^{-1}\right)$ para las especies marinas. Los resultados mostraron que la combinación de una baja densidad animal y la alimentación con una 
composición de diferentes ingredientes pero con valores nutricionales similares se asocia a unas tasas de crecimiento y a un perfil de nutrientes similares en la calidad del producto final. Es necesaria una investigación más a fondo sobre la nutrición para obtener información encaminada a la determinación de los estándares apropiados para la acuicultura orgánica de pargos y asegurar que el resultado final se ajuste a las preferencias de los consumidores.

Palabras clave: sostenible, orgánico, acuicultura de pargos.

\section{INTRODUCTION}

Gilthead sea bream is a carnivorous marine fish which belongs to the sparidae family. Sparidae aquaculture, commonly called bream and porgies, accounted for 244153 tonnes of fish in 2006 (FAO FishStatPlus 2008). These fish are farmed in Mediterranean countries; Greece is the leading producer, followed by Turkey, Spain, Italy and Israel (Basurco et al. 2011). Approximately 85\% of the production comes from sea cages (Greece, Turkey and Spain) and the rest from land based ponds (France, Italy and southern Spain) (Pavlidis and Mylonas 2011). Research into the production technologies, reproduction and nutrition of the species has improved broodstock maturation, spawning in captivity and egg/larva quality, and the protein and determined the energy requirements of the species. Therefore, growth rates and survival have been increased and the industry has expanded. However, this growth has also raised concerns, including environmental and sustainability issues. For instance, in terms of fish nutrition, a decline in the availability and increased prices of fish meal and fish oil have generated the need for research into possible replacements for these diet ingredients, mainly from plant sources, with the aim of promoting a sustainable aquaculture industry (Teles $e t$ al. 2011). Fish meal and fish oil have traditionally been used in sea bream diets because the former are high in proteins, normally containing 60 to $72 \%$ crude protein by weight, and the latter are rich in $n-3$ polyunsaturated fatty acids, which are essential in fish nutrition (Tacon and Metian 2008). The inclusion rate percentages of fish meal in diets for sea bream are usually $25-50 \%$ (Tacon and Metian 2008), but a fish meal replacement of up to $75 \%$ with plant proteins is achievable with no adverse effects on growth or protein retention (Sitja-Bobadilla $e t$ al. 2005). The use of fish meal in aquafeeds is expected to decrease from 2006 to 2020 by $31.3 \%$ for marine fish, $47.2 \%$ for salmon and $44.1 \%$ for trout (Tacon and Metian 2008).

Organic aquaculture aims to address these issues as well as a range of societal concerns about aquaculture. These concerns include (implicitly or explicitly): a) environmental issues relating to the sustainability of the entire production chain, such as the source of feed, environmental pollution and the carbon costs of processing and transport; $b$ ) health concerns related to additional benefits like natural remedies, beneficial additives (vitamins, minerals, etc.) and the reduction or elimination of health risk agents (e.g. salt, fat, etc.); c) food safety aspects concerning additives, contaminants and genetically modified organisms (GMOs); d) social motivations related to labour conditions, community involvement and fair trade; and e) animal welfare is- sues related to the conditions in which fish are raised. Consumers may favour products which address some or all of these concerns, especially if this is evidenced through "organic" certification, but ultimately the price and quality of the product are also crucial. According to Tacon and Brister (2002) the estimated global production of certified organic aquaculture products in 2000 was approximately 5000 tonnes, coming primarily from European countries. For 2003, Biao (2008) reported an estimated total production of 20000 tonnes. According to the Soil Association (www.soilassociation.org), UK production of organic salmon in 2008 was approximately 5500 tonnes, which is around $4 \%$ of the total UK salmon production and represents an increase of $12 \%$ since 2006. As organic aquaculture grows, more species are produced under certified programmes and more countries contribute to the total organic production. In 2007, several species, including Atlantic salmon, trout, carp, sea bream and bass, mussels, shrimp and microalgae, were produced organically around the globe, mainly in Europe, Asia, Oceania and Latin America (Bergleiter 2008). The global production in 2008 was 16000 tonnes of organic salmon, 8800 tonnes of organic shrimp, 7200 tonnes of carp, 3000 tonnes of mussels, 2000 tonnes of trout and 1000 tonnes of sea bream/sea bass (Bergleiter 2009, 2011, Mente et al. 2011). Organic aquaculture production is predicted to increase in the future to reach 200000 tonnes in 2015 and almost 1.2 million tonnes in 2030 (Lem 2004).

The current challenges for organic aquaculture are to improve the coordination between production and the market, and establish an appropriate framework to allow further development. However, research is also needed to demonstrate the benefits of organic aquaculture compared to conventional aquaculture. Certification schemes have proliferated in capture fisheries, and some authors are starting to question the extent to which they deliver the promised societal benefits (Kaiser and Edwards-Jones 2006, Kaiser and Hill 2010). In order to investigate whether organic aquaculture confers any or all of its supposed benefits, it is necessary to understand the production phases and the way that organic aquaculture interacts with the marine ecosystem. The recent EU Regulation (EC 2009) that provides detailed rules on organic aquaculture sets the maximum stocking densities for the organic production of sea bream at $4 \mathrm{~kg} \mathrm{~m}^{-3}$ in coastal lagoons and 15 $\mathrm{kg} \mathrm{m}^{-3}$ in open water systems. The stocking density is one of the main factors influencing the level of stress on fish, which in turn plays a significant role in any aquaculture system as it affects both animal welfare and productivity (Montero et al. 1999, Ashley 2007). Specifically, the stocking density has been negatively 
TABLE 1. - Diet formulation, proximate and amino acid composition of the experimental diets (\% of wet weight). Essential amino acid (A/E) ratio of each essential amino acid (EAA) was calculated as the percentage of the total EAA.

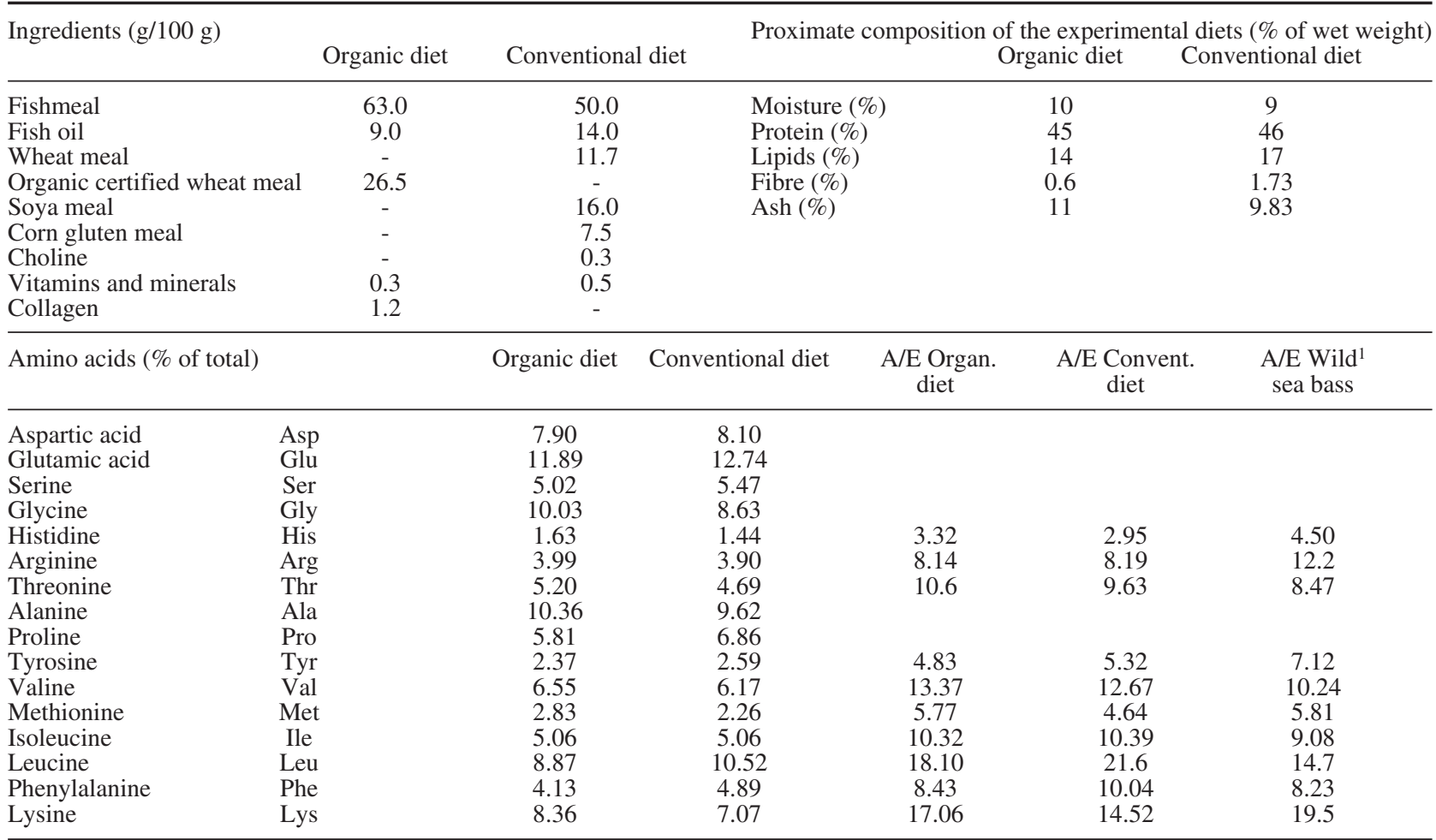

${ }^{1}$ Amino acid composition of wild sea bass by Özyurt and Polat (2006).

correlated with fish growth (Montero et al. 1999, Ellis et al. 2002). Stocking density can affect fish welfare because of its impact on fish social interactions and water quality (ESFA 2008).

In the present study sea bream were reared from $10 \mathrm{~g}$ to the commercial size of $350 \mathrm{~g}$ in sea cages in field conditions at two stocking densities. They were fed two nutritionally similar diet regimes with different ingredient compositions: an organic feed and a conventional feed. The fish in the "organic group" were kept at a very low stocking density $\left(4 \mathrm{~kg} \mathrm{~m}^{-3}\right)$ according to the EC regulation for sea bream reared in earthen ponds. The "conventional group" was stocked at a density of $15 \mathrm{~kg} \mathrm{~m}^{-3}$ according to the EC regulation for open water systems (sea cages). The study aimed to investigate the impact of the two stocking densities under "conventional" and "organic" conditions on sea bream growth, health, fish quality and body composition. In Greece, conventional sea cages are stocked at $15-20 \mathrm{~kg} \mathrm{~m}^{-3}$; hence, the stocking density of $15 \mathrm{~kg} \mathrm{~m}^{-3}$ can be considered conventional. To the knowledge of the authors, this is the first study that compares the combined effects of diet and stocking density on both fish quality and the environmental sustainability of organic aquaculture. It is a unique field trial since using a commercial facility to perform studies like this one is very unusual because the costs are extremely expensive. Thus, this study brings new information to light as there are relatively few published studies on the above issues.

\section{MATERIALS AND METHODS}

\section{Experimental animals and diets}

Sea bream, with an initial weight of $10 \pm 0.21 \mathrm{~g}$, were supplied by a commercial hatchery in Larymna, Greece. We used two treatments, organic and conventional, which differed in stocking density, type of feed, and whether antibiotic treatments were given to the fish. The "organic" fish were kept in two sea cages, $350 \mathrm{~m}$ away from the conventional cages in an area that is not used for cultivation by the aquafarm, at a density of $4 \mathrm{~kg} \mathrm{~m}^{-3}$. The "conventional" fish were kept in two cages at a density of $15 \mathrm{~kg} \mathrm{~m}^{-3}$ in an aquaculture farm in Larymna, Greece, for a period of 12 months (September 2007-September 2008). The physical and chemical parameters of the water, including temperature, dissolved oxygen and $\mathrm{pH}$, were measured monthly during the entire experimental period at $2 \mathrm{~m}$ water depth using a portable oxygen and $\mathrm{pH}$ meter (WTW Oxi 330i/ SET, Germany). The temperature ranged from $10.5^{\circ} \mathrm{C}$ to $26.7^{\circ} \mathrm{C}$ and the dissolved oxygen from 8.1 to $9.6 \mathrm{mg}$ $1^{-1}$. The $\mathrm{pH}$ ranged from 8 to 8.1 throughout the experiment. The fish were left to acclimate for one week. Organically produced feed (Table 1) that included sustainable certified fish meal, fish oil and organic wheat ( $45 \%$ crude protein, $14 \%$ fat, $0.6 \%$ fibre, $11 \%$ ash, no synthetic amino acids) was given daily to the organically farmed sea bream ad libitum by hand allowing natural feeding behaviour. The fish were weighed at 
monthly intervals, and the feeding level was adjusted as a percentage of the fish total biomass accordingly (to keep the feeding rate at a constant percentage of body weight). No antibiotics were given. The conventional fish were fed a commercial feed that included fish meal, fish oil, soy bean meal, wheat meal and corn gluten (46\% crude protein, $17 \%$ fat, $1.7 \%$ fibres, $9.8 \%$ ash) daily ad libitum by hand.

\section{Sample collection and analysis}

Fish were weighed monthly so that comparisons of the growth in the two treatments could be made. Ten fish were sacrificed every month and tissues were kept for further analysis. At the end of the trial, a total of 100 fish from both treatments were randomly sampled from the population for further analysis. Fish were sacrificed and samples of white muscle and liver tissues were dissected out on ice and frozen. Samples were stored at $-20^{\circ} \mathrm{C}$ until analysis. Samples of the diets were also taken and stored at $19^{\circ} \mathrm{C}$ to $20^{\circ} \mathrm{C}$ (room temperature) until further analysis. Samples of wild fish of similar weights were taken for comparisons of the proximate composition of white muscle.

The nutrient composition of the diets and muscle tissue samples was determined by proximate analysis and amino acid analysis (Tables 2, 3). Moisture was determined by thermal drying to a constant weight in an oven at $110^{\circ} \mathrm{C}$ for $24 \mathrm{~h}$. Crude protein contents were determined by Kjeldahl analyses (nitrogen $\mathrm{x}$ 6.25, Behr S4). Crude fat was determined by exhaustive Soxhlet extraction using petroleum ether (40$\left.60^{\circ} \mathrm{C}, \mathrm{BP}\right)$ on a Soxtherm SE416 Gerhardt System. The ash content was determined by dry ashing in

TABLE 2. - White muscle proximate composition (\% dry weight, mean \pm SE) of organic, conventional and wild sea bream, and white muscle amino acid (\% wet weight) of organic and conventional sea bream at the end of the experimental period. Amino acid composition of wild sea bass is shown for comparison.

\begin{tabular}{|c|c|c|c|c|}
\hline & & Organic & Conventional & Wild \\
\hline \multicolumn{2}{|l|}{ Moisture (\%) } & $73.43 \pm 1.02^{\mathrm{a}}$ & $67.37 \pm 2.59^{b}$ & $73.70 \pm 0.52^{a}$ \\
\hline \multicolumn{2}{|l|}{ Protein $(\%)$} & $79.14 \pm 2.71^{a}$ & $73.65 \pm 4.84^{b}$ & $80.69 \pm 1.09^{a}$ \\
\hline \multicolumn{2}{|l|}{ Lipid (\%) } & $10.80 \pm 3.48^{a}$ & $12.19 \pm 2.37^{\mathrm{a}}$ & $2.59 \pm 1.23^{b}$ \\
\hline \multicolumn{2}{|l|}{ Ash $(\%)$} & $0.47 \pm 0.03^{a}$ & $0.47 \pm 0.08^{a}$ & $0.36 \pm 0.08^{b}$ \\
\hline \multicolumn{2}{|c|}{ Amino acids ( $\%$ of total) } & Organic & Conventional & Wild $^{1}$ \\
\hline Aspartic acid & Asp & 8.88 & 8.57 & 9.14 \\
\hline Glutamic acid & Glu & 10.94 & 10.47 & 9.61 \\
\hline Hydroxyproline & Нyp & 0 & 0 & 0 \\
\hline Serine & Ser & 5.23 & 5.35 & 3.89 \\
\hline Glycine & Gly & 9.2 & 8.8 & 4.24 \\
\hline Histidine & His & 1.74 & 1.67 & 2.07 \\
\hline Arginine & Arg & 4.44 & 4.57 & 5.59 \\
\hline Threonine & Thr & 5.79 & 6.46 & 3.88 \\
\hline Alanine & Ala & 9.91 & 9.91 & 5.41 \\
\hline Tyrosine & Tyr & 2.78 & 2.78 & 3.26 \\
\hline Valine & Val & 6.42 & 6.9 & 4.69 \\
\hline Methionine & Met & 3.09 & 1.45 & 2.66 \\
\hline Isoleucine & Ile & 5.31 & 5.68 & 4.16 \\
\hline Leucine & Leu & 8.8 & 9.24 & 6.76 \\
\hline Phenylalanine & Phe & 3.49 & 3.67 & 3.77 \\
\hline Lysine & Lys & 9.04 & 9.58 & 8.93 \\
\hline
\end{tabular}

${ }^{1}$ Amino acid composition of wild sea bass by Özyurt and Polat (2006).

Means in a row followed by the same superscript are not significantly different $(P \leq 0.05)$.

TABLE 3. - a) Heavy metal concentration ( $\mathrm{Cu}, \mathrm{Zn}, \mathrm{Mn}, \mathrm{Hg}, \mathrm{Ni}$ and $\mathrm{Cr}-\mu \mathrm{g} \mathrm{g}{ }^{-1}$ dry weight) in muscle and liver of conventional and organic sea bream (values below the detection limit are denoted as not detected (n.d.), b) Dioxins and dioxin-like PCBs (pg g-1 sample TEQ WHO 1997) in the feeds and in the white muscle and liver of conventional and organically farmed sea bream (mean value \pm sd).

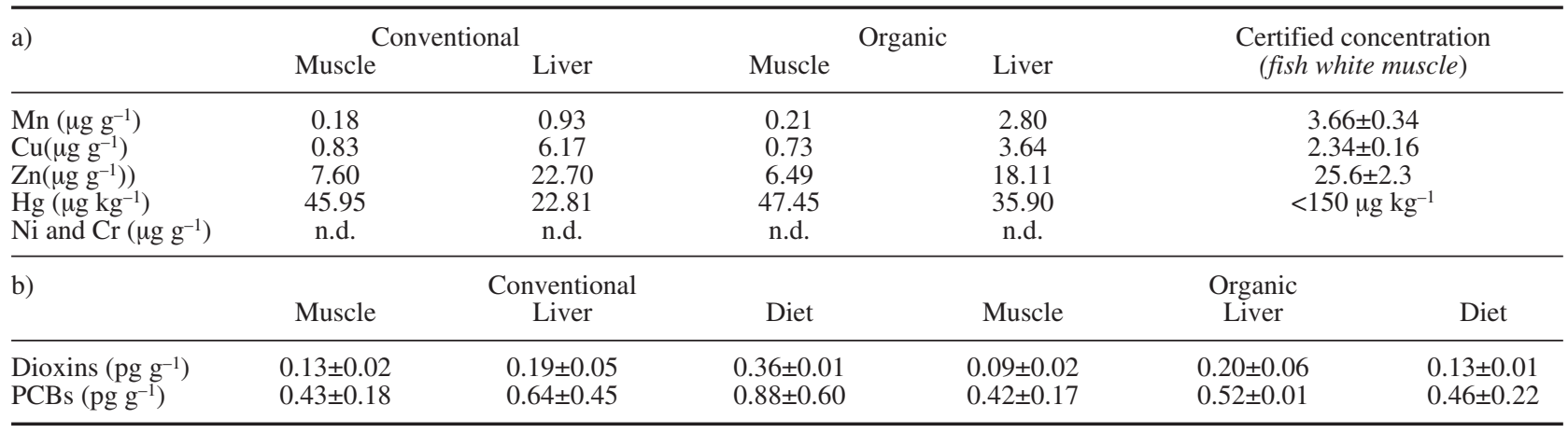


porcelain crucibles in a muffle furnace at $600^{\circ} \mathrm{C}$ for 5 hours. All methods are based on those described in AOAC (1995). The amino acid composition of the diets and the white muscle tissue from four fish per treatment were measured using the method given in Mente et al. (2002). Blood samples from a total of ten fish were centrifuged and serum was analysed for haematocrit values (Hct, \%), haemoglobin concentration $\left(\mathrm{Hb}, \mathrm{g} \mathrm{dl}^{-1}\right)$ and the red blood cell count $(\mathrm{RBC}$, $10^{6}$ cells $\mathrm{dl}^{-1}$ ). The red blood cell constants (mean cell haemoglobin concentration, $\mathrm{MCHC}, \mathrm{g} \mathrm{dl}^{-1}$; mean cell volume, $\mathrm{MCV}, \mathrm{fl}$ ) were calculated from $\mathrm{Hct}, \mathrm{Hb}$ and $\mathrm{RBC}$.

\section{Microbiological analysis}

Fish were killed by immersion in a mixture of water and ice, placed into insulated boxes, covered with ice and transferred to the laboratory within $4 \mathrm{~h}$. The microbiological media were supplied by LAB M (Lancashire, UK). Total viable counts (TVC) of mesophilic and phychrophilic bacteria, Enterobacteriaceae and B-glucuronidase positive E. coli were enumerated on skin and in white muscle. Skin samples $(1 \mathrm{~g})$ and white muscle $(10 \mathrm{~g})$ from the dorsal anterior area were aseptically cut off and placed into 9- and 90-ml sterile maximum recovery diluent (MRD, $0.85 \% \mathrm{NaCl}, 0.1 \%$ bacteriological peptone) respectively, and homogenised for 60s using a stomacher (BagMixer 400, Intersciences). Mesophilic and phychrophilic bacteria were counted on Tryptone Soy Agar (TSA) using the spread plate technique after incubation at $25^{\circ} \mathrm{C}$ for $48 \mathrm{~h}$ and $7^{\circ} \mathrm{C}$ for $96 \mathrm{~h}$ respectively. The pour plate technique was used for enumeration of Enterobacteriaceae on Violet Red Bile Dextrose agar (VRBGA), incubated at $37^{\circ} \mathrm{C}$ for $24 \mathrm{~h}$, and E. coli on Tryptone Bile Glucuronide Agar (TBGA), incubated at $44^{\circ} \mathrm{C}$ for $24 \mathrm{~h}$. Five replicate measurements were carried out for all microbiological parameters tested.

\section{Bacterial and heterotrophic nanoflagellate (HNF) counts}

Water samples were collected with a Niskin bottle from approximately 1-2 m below the surface from each cage. To enumerate HNF and bacteria, 5-15 $\mathrm{ml}$ and 1-5 $\mathrm{ml}$ of water respectively, were preserved with formaldehyde at a final concentration of $2 \%$. Samples were kept at $4{ }^{\circ} \mathrm{C}$ in the dark, filtered on black Nuclepore filters (pore size of $0.8 \mu \mathrm{m}$ and $0.2 \mu \mathrm{m}$ for HNF and bacteria respectively) and stained with DAPI (Porter and Feig 1980) within a few hours of sampling, and stored at $-20^{\circ} \mathrm{C}$ until counting. HNF and bacteria were enumerated using a ZEISS Axiostar epifluorescence microscope at $1000 \mathrm{x}$. The number of HNF was estimated by counting the total nanoflagellates and subtracting the individuals that exhibited autofluoresence (autotrophic cells).

\section{Analysis of heavy metals, dioxins and dioxin-like PCBs}

At the end of the experiment, three similarly sized fish were retained from the two fish categories (organic, conventional) for metal and dioxin analyses. Fillet and liver tissues were removed using plastic anatomy dissectors, put into petri dishes and kept at $-18^{\circ} \mathrm{C}$ until analysis. Muscle samples were analysed individually, while liver samples, due to their limited quantity, were pooled. Each sample therefore included the liver of 3 specimens. The analysis comprised dehydratation with a CHRIST GAMMA 1-20 lyophilisator (filet contained approximately $65 \%$ water and liver $60 \%$ ), homogenisation in a porcelain mortar and digestion of about 1 $\mathrm{g}$ of dried tissue with $10 \mathrm{ml}$ of $\mathrm{HNO}_{3}$ in a microwavedevice (CEM MDS 2100). After digestion the samples were diluted with distilled water to $20 \mathrm{ml}$. A Varian SpectrAA 20 Plus flame atomic absorption spectrophotometer was used to determine the $\mathrm{Cu}, \mathrm{Zn}, \mathrm{Cr}, \mathrm{Ni}, \mathrm{Fe}$ and $\mathrm{Mn}$ concentrations. The accuracy and precision of the analytical methodology were tested with the reference material NRCC-Dorm-2 of homogenised dogfish muscle (Table 3).

Muscle and liver samples were blended and ground with an appropriate quantity of anhydrous sodium sulphate. After extraction with dichloromethane in a Soxhlet extractor, the organic fraction was evaporated, dried and weighed to calculate the lipid content (Papadopoulos et al. 2004). For the determination of PCDDs/Fs and non-ortho PCBs, the samples were cleaned according to the method described by Costopoulou et al. (2006). The quantification of PCDD/Fs, non-ortho, mono-ortho and indicator PCBs was performed by HRGC-HRMS (EI) in MID mode on a Trace GC gas chromatograph (ThermoFinnigan) coupled to a MAT-95 XP mass spectrometer (ThermoFinnigan) equipped with a CTC A 200S autosampler at 10000 resolving power (10\% valley definition). The instrumental conditions and purity control criteria were in accordance with the EPA 1613 and EPA 1668A methods. The concentration and recovery were quantified by the isotopic dilution method. The limit of detection (LOD) for each congener was determined as the concentration in the extract that produced an instrumental response in two different ions monitored with a signal to noise ratio of $3: 1$ for the less sensitive signal (EU Directive 2004/44/EC). The WHO-98 toxicity equivalent factors (TEF) were used for toxicity equivalent (TEQ) calculations. The WHO-PCDD/F-TEQ value (quality control) showed an average of $3.26 \mathrm{pg} \mathrm{g}^{-1}$ with a confidence interval of 2.74-3.78 $\mathrm{pg} \mathrm{g}^{-1}$ (confidence level 95\%). The WHOPCB-TEQ value (sum of non-ortho and mono-ortho PCBs) showed an average of $4.31 \mathrm{pg} \mathrm{g}^{-1}$ with a confidence interval of 3.62-5.00 $\mathrm{pg} \mathrm{g}^{-1}$ (confidence level 95\%). The LOD was determined for each congener to be between 0.1 and $0.15 \mathrm{pg} \mathrm{g}^{-1}$ of fat. Recovery ranged between $70 \%$ and $120 \%$. 


\section{Data analysis}

The data (expressed as mean $\pm \mathrm{SEM}$ ) were checked for homogeneity of variances, and logarithmic transformations were made when necessary. Differences between the two treatments (organic vs. conventional) were determined by t-tests using SPSS 14 . Differences between means were assessed by ANOVA followed by Tukey multiple comparison tests for multigroup comparisons. Pearson correlation coefficients between dietary and tissue amino acid composition were calculated and a probability level of $P \leq 0.05$ was considered statistically significant for all statistical tests.

\section{RESULTS}

\section{Growth}

At the start of the experiment there were no significant differences between the mean values or the range of initial body weights of the fish in the two groups $(P>0.05)$. The organic group showed a statistically higher mean weight in January and March (months 5 and $7, P<0.05$ ) than the conventional group. At the end of the experiment the final mean weights of the organic group ( $246.94 \pm 3.98 \mathrm{~g})$ were higher in comparison to the conventional group $(218.97 \pm 3.94 \mathrm{~g})$ but they were not statistically different. The specific growth rate (SGR, \%/ day) was $0.87 \pm 0.06$ for the organic group and $0.84 \pm 0.05$ for the conventional group respectively, and were not significantly different. The hepatosomatic index (HSI) was calculated every time fish were sampled (September, January, March, June and September a year after) during the entire experimental period. The HSI ranged between 1.06 and $1.61 \%$ for the conventional fish and 1.21 and $2.07 \%$ for the organic fish respectively, but the differences were not significant $(P>0.05)$.

\section{Biochemical and haematology analysis}

The white muscle proximate composition of the organic, conventional and wild fish at the end of the experiment is shown in Table 2 . The white muscle dry matter, protein, lipid and ash content varied between $26.29 \%$ and $32.62 \%, 21.02 \%$ and $24.03 \%, 0.73 \%$ and $3.99 \%$ and $1.38 \%$ and $1.78 \%$ respectively. The moisture and protein contents were significantly lower in the conventional fish compared to the organic and wild fish $(P<0.05)$; however, no significant differences were found between organic and wild fish. The white muscle lipid content was higher for the conventional fish compared to the organic fish and both were significantly higher compared to the wild fish $(P<0.05)$. The wild fish had the lowest white muscle lipid content. The ash content of the white muscle of organic and conventional fish did not differ significantly; however, wild fish showed a significantly lower ash content $(P<0.05)$. We also determined the liver lipid content of the conventional and organic sea bream during the

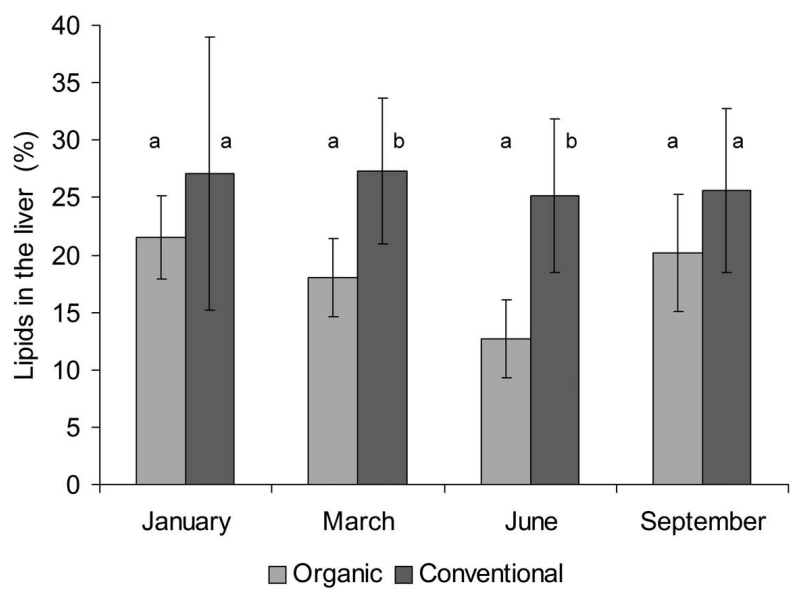

FIG. 1. - Lipid content (\%, dry matter) of the liver from organic and conventional sea bream fed the experimental diets for 12 months. For each month, different letters denote significant differences $(P \leq 0.05)$ between conventional and organic groups.

entire experimental period. The results clearly showed that the organic fish had a lower liver lipid content than the conventional fish during the entire trial (Fig. 1). However, these differences were not statistically significant at the last sampling point, although differences were recorded in March $(\mathrm{t}=3.68, P<0.05)$ and June $(\mathrm{t}=4.14, P<0.05)$. The haematological characteristics showed higher values for the organic fish than the conventional fish. The haematocrit value (three replicates) was higher and statistically significant in organic fish $(55.8 \pm 1.1 \%)$ in comparison with the conventional fish $(50.1 \pm 1.21 \%, P<0.05)$. The haemoglobin concentration was $12.46 \pm 0.34 \mathrm{~g} \mathrm{dl}^{-1}$ for the organic fish and $11.63 \pm 0.03 \mathrm{~g} \mathrm{dl}^{-1}$ for conventional fish. The mean cell haemoglobin concentration (MCHC) was $22.58 \pm 0.17$ $\mathrm{g} \mathrm{dl}^{-1}$ for the organic fish and $22.1 \pm 0.36 \mathrm{~g} \mathrm{dl}^{-1}$ for the conventional fish. The mean cell volume (MCV) was lower for the organic fish $(141.04 \pm 0.48 \mathrm{fl})$ than for the conventional fish $(122.8 \pm 1.44 \mathrm{fl})$, but not significantly different $P>0.05$.

Compared to the conventional diet, the organic diet contained more glycine, histidine, threonine, alanine, methionine, valine and lysine, while the content of aspartic and glutamic acid, serine, proline, tyrosine, leucine and phenylalanine was lower (Table 1). As there were no data on amino acid composition in the muscle of wild sea bream (Grigorakis 2007), the amino acid profile of wild sea bass was used for comparisons. The amino acid composition of the white muscle of the wild sea bass showed that the concentrations of aspartic acid, glutamic acid and lysine were the highest. A similar pattern was observed in the white muscle of the conventional and organic sea bream as well as higher concentrations of leucine and alanine (Table 2). The essential protein amino acid composition of the white muscle of the wild sea bass (on the basis of the $r^{2}$ values) was correlated more with the essential amino acid composition of the organic diet $\left(r^{2}=0.86, P<0.05\right)$ than the conventional diet $\left(r^{2}=0.77, P<0.05\right)$. 

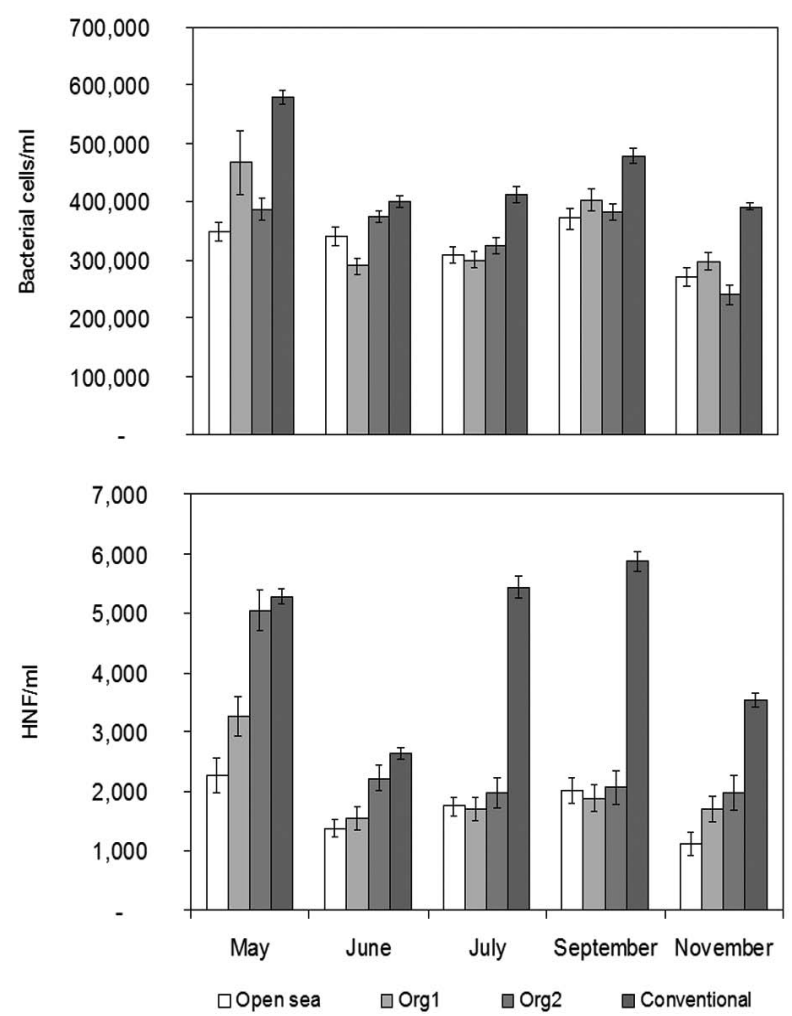

FIG. 2. - Abundance of bacteria and heterotrophic nanoflagellates (HNF) in the experimental cages (Org1, Org2), the conventional cage and the reference station (open sea).

\section{Microbiological analysis}

Both Enterobacteriaceae and E. coli on skin and white muscle were found to be below the detection limit of $10 \mathrm{cfu}^{-1}$ in all samples. Total viable counts of psychrophilic bacteria were below the detection limit of $100 \mathrm{cfu} \mathrm{g}^{-1}$ in all samples. Total viable counts (TVC) of total mesophilic bacteria in sea bream skin and muscle $4 \mathrm{~h}$ after being caught and sacrificed (five replicates) were almost identical $(P>0.05)$ for both conventional $\left(1.7 \pm 0.5 \times 10^{3} \mathrm{cfu} \mathrm{g}^{-1}\right)$ and organic $\left(1.4 \pm 0.3 \times 10^{3} \mathrm{cfu} \mathrm{g}^{-1}\right)$ skin, and for both conventional $\left(8.7 \pm 3.5 \times 10^{2} \mathrm{cfu} \mathrm{g}^{-1}\right)$ and organic $\left(1.3 \pm 0.4 \times 10^{3} \mathrm{cfu} \mathrm{g}^{-1}\right)$ white muscle.

\section{Bacterial and heterotrophic nanoflagellate (HNF) counts}

The water column bacterial abundance was always higher in the conventional cage (391515-579750 cells $\mathrm{ml}^{-1}$ ) than at the reference station (270428-371333 cells $\left.\mathrm{ml}^{-1}\right)(P>0.05)$. In most cases, the bacterial abundances of the organic cages and the reference stations were similar (Fig. 2). A similar trend occurred for HNF, with the highest abundances always observed in the conventional cage (2646-5875 individuals $\mathrm{ml}^{-1}$ ) $(P>0.05)$. With the exception of the first sampling, the HNF abundances of the organic cages and the reference station were similar (Fig. 2).

\section{Analysis of heavy metals, dioxins and PCBs}

Muscle and liver heavy metal concentrations $(\mathrm{Cu}$, $\mathrm{Zn}, \mathrm{Mn}, \mathrm{Hg}, \mathrm{Ni}$ and $\mathrm{Cr}$ expressed as $\mu \mathrm{g} \mathrm{g}{ }^{-1}$ dry weight) of conventional and organic sea bream are presented in Table 3a. The summarised results showed that the two fish tissues bioaccumulate metals to differing degrees: in all cases the liver had metal levels three to eight times higher than the muscle. $\mathrm{Cr}$ and $\mathrm{Ni}$ concentrations were under $0.001 \mu \mathrm{g} \mathrm{g}^{-1}$ and are thus not shown. Although the organic fish showed generally lower levels than the fish fed with conventional food, these differences were not statistically significant $(P>0.05)$. Organically farmed sea bream was found to contain low levels of dioxins and dioxin-like PCBs (Table 3b). The dioxin levels in the white muscle of the organically farmed fish were lower than the dioxin levels of the conventional white muscle $\left(0.09\right.$ and $0.13 \mathrm{pg} \mathrm{g}^{-1}$ tissue respectively) but both were below the EU limit (EU limit, 4pg WHO-TEQ/g fresh weight). The dioxin levels in the liver tissue of both the organic and conventional groups of sea bream were very low and again below the $25 \mathrm{pg} \mathrm{g}^{-1}$ set by the EU as a limit. PCBs for the organic and conventional white muscle of the farmed sea bream were $0.4 \mathrm{pg} \mathrm{g}^{-1}$ tissue, which is lower than the EU limit of $8 \mathrm{pg} \mathrm{g}^{-1}$ tissue. PCBs were lower for the organic liver tissue $\left(0.52 \mathrm{pg} \mathrm{g}^{-1}\right)$ in comparison with the conventional liver tissue $\left(0.64 \mathrm{pg} \mathrm{g}^{-1}\right)$. Both values were much lower than the $25 \mathrm{pg} \mathrm{g}^{-1}$ set as the limit by the EU. Organic feed has lower levels of dioxins and PCBs but both feeds had much lower values than the EU limits (Table 3b).

\section{DISCUSSION}

Modern aquaculture represents a major revolution in the production of fish and foods of aquatic origin. The rapid expansion of aquaculture has often been referred to as the "blue revolution". The European Commission proposed a strategy in 2002 that aims to control the development potential while guaranteeing environmental sustainability, high health standards and product quality. Organic aquaculture is still in its infancy. Its emergence and growth is a market-driven phenomenon originating from growing consumer awareness of health and environmental issues, and from the industry's response to changes in the market. Organic aquaculture relies on biological processes to manage the welfare of the animals, the nutrient inputs, the waste produced and the environment in which they live (EC 2007), which are interconnected processes. Council Regulation (EC) No 834/2007 and 710/2009 (EC 2007, 2009) on aquaculture production sets a number of guidelines concerning the origin of animals, husbandry practices, breeding, feeds and feeding, disease prevention and veterinary treatment. Organic principles imply several changes to aquaculture practices, including the use of feeds that comply with organic standards, such as the exclusion of GMOs and the compliance with the 
principle of sustainable exploitation of fisheries for fish meal and fish oil as well as lower stocking densities, in order to develop a sustainable aquatic system that maximises animal welfare and minimises the environmental impact (Boehmer et al. 2005, Biao 2008, EC 2007, 2009, Mente et al. 2011).

Fish meal and fish oil have been used extensively in carnivorous fish nutrition. However, it is becoming necessary to rely less on these commodities for sustainability and economic reasons. It has been predicted that by 2020 the use of fish meal and fish oil in aquafeeds will be reduced by $44.5 \%$ and $15.5 \%$ respectively (Tacon and Metian 2008). In future, fish meal and fish oil will become strategic ingredients in specialist diets such as starter, brood stock and finisher diets, in relation to different critical stages of the life cycle of farmed fish, especially carnivorous fish (Tacon and Metian 2008). Previous studies on diets for European sea bass have shown that vegetable oils can replace up to $60 \%$ of the fish oil with no detrimental effects for fish growth, although alterations in the fatty acids in tissues may reduce the final quality of the product (Turchini et al. 2009). Results from the AQUAMAX project in 2006 (www http://www.aquamaxip.eu/) reported that in farmed sea bream, an inclusion level of $40-45 \%$ of fish meal was used in aquafeeds, and a percentage of $15 \%$ of fish meal concurrent with a level of $10 \%$ of fish oil was targeted for 2010. All-plant protein-based diets containing soybean meal, cottonseed meal, and middlings from corn and wheat, are supplemented with essential amino acids in the aquaculture of several sparidae species (Teles et al. 2011). However, in organic aquaculture, the diets cannot be supplemented with synthetic amino acids according to the EC regulation 2009, which is a bottleneck in the search for alternatives to fish meal protein and the use of plant protein sources.

Studies have shown that for the adult sea bream feeds the protein content has to be $40-45 \%$, the optimum lipid content has to be $14-22 \%$, and the maximum carbohydrate content 20\% (Gomez-Requeni et al. 2003, Sanchez-Muros et al. 2003, Teles et al. 2011). The results of the proximate composition of feeds used in our study were appropriate for sea bream and agree with the aforementioned studies. The results of this study showed that the organically farmed sea bream performed well during the entire experimental period. Notably, in two of the sampling points the organic group had a statistically higher mean weight than the conventional group, although final weights after 12 months were not significantly different. The organic diet used in the present study had a lower lipid content than the conventional diet (14\% vs. $17 \%$ respectively). This is in accordance with the general principles of sustainable aquaculture production, according to which there should be lower inputs and a reduced dependence on fish meal and fish oil, which is important especially for carnivorous species like the sea bream (Tacon and Brister 2002, Boehmer et al. 2005). Hence, it is noteworthy that the findings show that the fish fed with an organic diet had a good performance, despite the fact that the lipid content and thus the dietary energy content was lower in the organic diet than in the conventional one. However, importantly, the essential amino acid composition of the organic diet was correlated more with the white muscle of the wild fish than the conventional diet, and thus meets the dietary protein requirements of this species. The application of organic farming principles in the present study had a positive effect on the nutritional status of the fish. The hepatosomatic index (HSI) is indicative of the nutritional status as it is a crude measure of the level of energy reserves, and has been negatively linked to the stocking density (Ellis et al. 2002). The HSI can also be affected by the diet, and increases with increasing dietary lipid content (Lie et al. 1986). The results of the present trial showed that HSI was higher in the organic group in comparison to the conventional group, which corresponds to previous findings on the effects of the stocking density on the HSI and despite the lower lipid content of the organic diets. However, more research into the nutrient requirements of aquatic organisms as well as advances in feed technology are needed for organic aquaculture to formulate species-specific fish organic aquafeeds.

There are few studies on the behaviour and welfare of fish at farm stocking densities, mainly due to the difficulties of observing fish under commercial conditions and the complexity of the interrelation between stocking density and water quality (ESFA 2008). Stocking density can affect fish welfare due to its impact on fish social interactions and water quality (ESFA 2008). In cage systems in Greece, farmers keep their stock at densities in the $15-20 \mathrm{~kg} \mathrm{~m}^{3}$ range or more, depending on the fish size, site and cage characteristics (the water currents and net cage status determining the water renewal inside the cage, and accordingly the availability of oxygen). Papoutsoglou et al. (1998) found that the highest specific growth rate and the lowest food conversion ratio were observed for sea bass of the highest stocking density (325 and 650 ind. $\mathrm{m}^{-3}$, which coincided with poorer water quality). No significant differences were found in the haematocrit values, or in hepatosomatic indices in the groups of fish held at any of the stocking densities. Terova et al. (2005) demonstrated that a high rearing density $\left(80\right.$ and $\left.100 \mathrm{~kg} \mathrm{~m}^{-3}\right)$ of sea bass affects the glucocorticoid receptor mRNA, the abundance of which in the liver decreased inversely with blood cortisol levels. Montero et al. (1999) found that a high stocking density $\left(40 \mathrm{~kg} \mathrm{~m}^{-3}\right)$ produces crowding stress that alters some physiological and biochemical parameters in sea bream juveniles. They found that the stocking density increases the modified lipid metabolism in order to help meet the increased energy demand. Di Marco et al. (2008) reached similar conclusions for ongrowing sea bass. The authors found no differences in growth and survival in sea bass kept at 15,30 or $45 \mathrm{~kg} \mathrm{~m}^{-3}$ for 6 weeks. The results indicate 
that a stocking density of $45 \mathrm{~kg} \mathrm{~m}^{-3}$ for 6 weeks did affect the energetic status of sea bass and their sensitivity to a subsequent crowding stressor. After exposure to adverse conditions fish require a recovery time that is related to the magnitude of the adverse effect (Di Marco et al. 2008). Canario et al. (1998) found that gilthead sea bream held in tanks at a density of $3.2 \mathrm{~kg}$ $\mathrm{m}^{-3}$ grew $25 \%$ less than fish at a density of $0.35 \mathrm{~kg} \mathrm{~m}^{-3}$, and concluded that growth in fish although negatively correlated with stocking density did not seem to be related to intraspecific competition as evidenced by changes in size variability. Behavioural changes and other factors related to water quality may be involved.

The quality and the nutritional characteristics of the final product are of great significance and have various implications, including the consumer's acceptance of the product along with other marketing parameters. In particular, organic aquaculture aims to produce high quality products (EC 2007, 2009). The edible part of the sea bream is the muscle, and hence its composition is probably the most important factor in terms of fish quality. Previous findings suggest that sea bream produced in intensive farming systems have lower moisture content and higher lipid content compared to wild fish $(70.7 \%$ vs. $77.2 \%$ and $5.3 \%$ vs. $1.4 \%$, respectively), while the protein content is not significantly different between farmed and wild fish $(20.4 \%$ vs. $20.2 \%)$ (Grigorakis 2007). In the present study, the white muscle of the organically produced fish had significantly higher moisture than the conventionally reared fish. Moreover, neither the moisture nor the protein contents of organic fish differed significantly from that of wild fish, unlike conventional fish. Fat deposition in fish tissues is affected by many factors, including dietary lipid content, which has been positively related to the fat content in tissues (Grigorakis 2007). Hence, the lower dietary lipid content of the organic diet probably resulted in the lower lipid content in the white muscle and liver of the organic sea bream in comparison with the conventional group; however, the difference was not significant at any time in the experimental period. The latter could be due to the lower stocking density and the less stressful conditions in which the organic fish were reared, as high stocking densities can lead to increased lipid mobilisation (Montero et al. 1999).

Kaushik (1998) calculated the theoretical essential amino acid requirement profile of gilthead sea bream and sea bass and found that the highest requirements of both species were for lysine, arginine and leucine. Özyurt and Polat (2006) reported that the main amino acids in sea bass muscle were aspartic acid, glutamic acid and lysine. When body composition of wild sea bass is used as the ideal essential amino acid profile, the lysine, leucine and arginine requirements are higher than the other essential amino acids (Table 1). The amino acid profile of the conventional diet, particularly the lysine content, appeared to be unsatisfactory. Lysine deficiency can cause a reduction in weight gain and in the protein utilisation ratio (Kaushik 1998). In the present study, the haematocrit levels of organic fish were significantly higher than that of the conventional fish, indicating that the fish were in good health given the good growth results and the less stressful conditions for the organic group; however, it could also signify an increased oxygen carrying capacity of the blood, possibly due to a higher energy demand (Montero et al. 1999). There are various complex factors that affect the haematology parameters (Martinez et al. 1994) and further investigation is needed for a better understanding of the process.

Within the context of responsible, sustainable, organic aquaculture the nutritional value of the feed ingredients and feed inputs is very important, and poor processing, handling and storage may contaminate the feed, which would have a negative impact on the health of the farmed aquatic species. Consumption of contaminated food by fish and their exposure to toxins, usually defined as bioconcentration, bioaccumulation or biomagnifications, could affect the consumers. The highest concentrations of contaminants were found in the liver, which showed higher pollutant levels than the muscle. Serrano et al. (2008) found that wild gilthead sea bream from the western Mediterranean showed significantly higher concentrations of DDTs and PCBs than farmed fish from the same area. They concluded that the load of organochlorine pollutants in fish tissues is related to seasonal changes in the feeding behaviour of the species and their feeds (Serrano et al. 2008). The fish diets stand out as an important source of organic persistent contaminants (Serrano et al. 2003, Nácher-Mestre et al. 2009). The distribution of the PCB congener in tissues of sea bass collected in two fish farms in Ria de Aveiro resembled that of fish fed a pelleted diet, suggesting that a commercial diet is a major source of PCBs (Antunes and Gil 2004). Abalos et al. (2008) fed farmed gilthead sea bream with a dry feed spiked with a low level $23 \mathrm{ng}$ WHO-TEQ/kg of feed PCDD/fs mixture to assess the bioaccumulation in the muscle and liver tissues after 390 days of exposure. They found that the concentrations in the fish exposed to $\mathrm{PCDD} / \mathrm{F}$ were $5.50 \mathrm{pg} \mathrm{WHO}-\mathrm{TEQ} / \mathrm{g}$ fresh weight in flesh and $8.45 \mathrm{pg}$ WHO-TEQ/g fresh weight in liver tissue. These levels are 24-fold and 14-fold higher than the background levels. Thus, although sea bream were fed on low dioxin contaminated feed, high bioaccumulation took place at the beginning of the rearing process with little bioaccumulation later in the exposure. In this study, although the organic fish generally had lower heavy metal levels than the fish fed with conventional food, these differences were not statistically significant $(P>0.05)$ mainly due to the limited sample size (only 3 fish were analysed). The present results are therefore only indicative and a more extensive analysis is needed in the future. The bioconcentrations of metals in organically fed fish are generally lower than those of farmed fish in the same area (North Evoikos Gulf, Larymna Bay; Simboura and Catsiki 2009). Industrial activity in the last century has led to increased levels of dioxins 
and the related dioxin-like PCBs in the environment, including the oceans, which has led to bioaccumulation in aquatic organisms (Froescheis et al. 2000, Storelli et al. 2007). Fish meal and especially fish oil from polluted areas have been linked with these pollutants, and hence there is the potential risk that farmed fish will be contaminated through their feed, with the consequent implications for the quality of the final product and human nutrition and health (Lundebye et al. 2004, Bell et al. 2005, Bethune et al. 2006, Mozaffarian and Rimm 2006). The European Commission, recognising the potential risks originating from the accumulation of these substances, drastically reduced the permitted levels of dioxins in both animal feed and food for humans in 2000. It has set maximum limits in feedstuffs and fish, and requires the member states to monitor the levels of dioxins in foodstuffs and to report to the EC (EC 2001, 2006). The EU limit for fish is $4 \mathrm{pg} \mathrm{g}^{-1}$ fresh weight or $4 \mathrm{ng}$ WHO-TEQ/kg fish wet weight. The results of this study showed that the organically farmed and conventionally farmed sea bream were well below current European limits for dioxins and PCBs. The contaminant concentrations in the tissues of both the organic and conventional fish were relatively low, especially in comparison with fish coming from polluted areas (Dural et al. 2010), and are indicative of good rearing conditions and a safe final product.

Low population levels of Enterobacteriaceae and $E$. coli indicate that both the cultivation and slaughter of fish took place under good hygiene conditions. The initial total bacterial population of freshly harvested fish depends on various factors. Atlantic horse mackerel (Trachurus trachurus) caught off the Portuguese Atlantic coast and stored in ice until arrival at the laboratory (after $20 \mathrm{~h}$ ) had TVC on their skin above the $10^{4}$ cfu g ${ }^{-1}$ level (Mendes et al. 2005). Sea bream and sea bass taken from an aquaculture facility in the Aegean Sea had an initial TVC below $10^{3} \mathrm{cfu} \mathrm{g}^{-1}$ (Cakli et al. 2007). The water quality, fish handling, storage and transport conditions as well as the time of microbiological sampling all influence the microbial population of fresh fish. Therefore, comparisons with data from other studies are not reliable. Bacterial activity is the main cause of quality deterioration of fresh fish (Gram and Huss 1996). A low initial bacterial population is desirable, since fish can be stored for a longer time before rejection due to microbiological spoilage. Farmed fish, such as sea-bream and sea-bass, with low initial microbial counts can be stored in ice up to 15 days (Cakli et al. 2007).

Although the water column bacterial abundance has been found to be one of the biological parameters most affected by fish culture (Sará 2007), it has not been widely used to monitor the environmental impact of aquaculture. In our case, it could be clearly seen that the bacterial abundance was always higher in the conventional cage. In addition, the bacterial abundance in the organic cage was similar to that of the seawater away from the cages (open sea). Since heterotrophic bacteria respond rapidly to changes in organic substrates and/ or inorganic nutrients (Caruso et al. 2003), these differences in abundances were most probably due to the higher fish density and excretion in the conventional cages. Remarkably, this bacterial response was also reflected at the next trophic level, i.e. the HNF. This suggests that conventional versus organic fish aquaculture has different consequences for planktonic food webs in the water column, affecting the mineralisation of carbon and recycling of inorganic nutrients via the microbial loop (Azam et al. 1983). This finding requires further investigation. Due to practical constraints the present study only involved two cages with different regimes, and thus further studies are clearly necessary, with replicate treatments and, ideally, examining the consequences of stocking density and feed choice separately. Nevertheless, the results show the possible benefits of organic aquaculture practices for the consumer, the fish, and the environment.

\section{CONCLUSION}

The forthcoming reform of the Common Fishery Policy (CFP), which is the main body of legislation regulating human activities in European Seas, requires an 'ecosystem approach' to fisheries management to be adopted in order to increase sustainability. Similar considerations apply to aquaculture: both aquaculture and fisheries industries evolve within an institutional framework that attaches major importance to ecological considerations, such as biodiversity, ecosystem health and sustainable use of the marine ecosystem. Safeguarding ecosystem benefits for future generations is a principle of sustainable management and development. The development of aquaculture could satisfy the growing demand for high protein food in both developed and developing societies, but further research is needed to increase production efficiency and to ensure sustainable and environmentally friendly production. Organic aquaculture is one of the possible solutions.

The study focused on the effects of the two production methods (conventional, organic) on sea bream growth and on the nutritional and biochemical characteristics, microbial counts and contaminant levels in the fish tissues. It also examined the indirect effects on the structure of the planktonic trophic web. The stocking density, within the range of the stocking densities tested, and feed influence the final quality of sea bream. A lower stocking density combined with feed that is nutritionally similar to conventional feed results in a similar growth, nutritional status and health status of the fish. The most important result of the present study is the similarity in the growth of the fish fed the organic diet and those fed the conventional diet. The liver of the two groups of fish evidenced the dietary differences. Importantly, the white muscle of the organically produced fish had significantly higher moisture in comparison to the conventionally reared fish. Moreover, neither the moisture nor the protein contents of the 
organic fish differed significantly from the wild fish, unlike the conventional fish. Interestingly the essential protein amino acid composition of the white muscle of the wild sea bass was correlated more with the essential amino acid composition of the organic diet than the conventional diet. Using the body composition of wild sea bass as the ideal essential amino acid profile, it can be seen that the lysine, leucine and arginine requirements are higher than the other essential amino acids. The amino acid profile of the conventional diet, particularly the lysine content, appeared to be unsatisfactory. If the improved product quality results in increased consumer interest then organic aquaculture could become favoured over traditional culture systems, thus generating increased environmental benefits.

\section{ACKNOWLEDGEMENTS}

This research was co-funded by the European Commission and the Hellenic Ministry of Rural Development and Food. The authors wish to express their thanks to Bitsakos Aquaculture farm and Zoonomi Aquafeed Company for their help. The authors are grateful to Professor G. Pierce and Dr. B. Santos and to anonymous referees for their comments on the manuscript.

\section{REFERENCES}

Abalos M., Abad E., Estevez A., Solé M., Buet A., Quirós L., Piña B., Rivera J. 2008. Effects on growth and biochemical responses in juvenile gilthead sea bream "Sparus aurata" after longterm dietary exposure to low levels of dioxins. Chemosphere 73: $303-310$

Antunes P., Gil O. 2004. PCB and DDT contamination in cultivated and wild sea bass from Ria Aveiro, Portugal. Chemosphere 54: $1503-1507$

AOAC 1995. Official methods of analysis of the Association of Official Analytical Chemists International, 16th ed. Association of Official Analytical Chemists, Arlington, VA, USA.

Ashley P.J. 2007. Fish welfare: Current issues in aquaculture. Appl. Anim. Behav. Sci. 104: 199-235.

Azam F., Fenchel T., Field J.G., Gray J.S., Meyer-Reil L.A., Thingstad F. 1983. The ecological role of water-column microbes in the sea. Mar. Ecol. Prog. Ser. 10: 257-263.

Basurco B., Lovatelli A., Garcia B. 2011. Current status of sparidae aquaculture. Chapter 1. In: Pavlidis M., Mylonas C. (eds.), Sparidae: Biology and aquaculture of gilthead sea bream and other species. Wiley Blackwell, pp. 408

Bell J.G., McGhee F., Dick J.R., Tocher D.R. 2005. Dioxin and dioxin-like polychlorinated biphenyls (PCBs) in Scottish farmed salmon (Salmo salar): effects of replacement of dietary marine fish oil with vegetable oils. Aquaculture 243: 305-314.

Bergleiter S. 2008. Organic Aquaculture. In: Willer H., YussefiMenzler M., Sorensen N. (eds.), The World of Organic Agriculture. Statistics and Emerging Trends. International Federation of Organic Agriculture Movements (IFOAM), Bonn, Germany and Research Institute of Organic Agriculture (FiBL), Frick, Switzerland, pp. 83-87.

Bergleiter, S., Berner, N., Censkowsky, U., Guliá-Camprodon, G. 2009 Organic Aquaculture 2009 - Production and Markets. Munich, Germany, ISBN 978-3-00-026707-9.

Bergleiter S. 2011 Organic aquaculture - from a "nice niche" to the "whole cake"? increasing the organic share of world aquaculture. European Aquaculture Society annual meeting, Rhodes Greece, October 18.

Bethune C., Seierstad S.L., Seljeflot I., Johansen O., Arnesen H. Meltzer H.M., Rosenlund G., Frøyland L., Lundebye A.K. 2006. Dietary intake of differently fed salmon: a preliminary study on contaminants. Eur. J. Clin. Invest. 36: 193-201.

Biao X. 2008. The development of and prospects for organic aquaculture worldwide. Outlook Agr. 37: 255-260.

Boehmer S., Gold M., Hauser S., Thomas B., Young A. 2005. Organic Aquaculture. United States Department of Agriculture, National Agricultural Library. Retrieved on 27/06/2009 from http://www.nal.usda.gov/afsic/AFSIC_pubs/afnotes5.htm

Cakli S., Kilinc B., Cadun A., Dincer T., Tolasa S. 2007. Comparison of effects of slurry ice and flake ice pretreatments on the quality of aquacultured sea bream (Sparus aurata) and sea bass (Dicentrarchus labrax) stored at $4^{\circ} \mathrm{C}$. Food Control 18: 391-397.

Canario A.V.N., Condeça J., Power D.M. 1998. The effect of stocking density on growth in the gilthead sea-bream, Sparus aurata (L.). Aquac. Res. 29: 177-181.

Caruso G, Genovese L., Mancuso M., Modica A. 2003. Effects of fish farming on microbial enzyme activities and densities: comparison between three Mediterranean sites. J. Appl. Microbiol. 37: 324-328.

Costopoulou D., Vassiliadou I., Papadopoulos A., Makropoulos V., Leondiadis L. 2006. Levels of dioxins, furans and PCBs in human serum and milk of people living in Greece. Chemosphere 65: $1462-1469$

Di Marco P., Priori A., Finoia M.G., Massari A., Mandich A., Marino G. 2008. Biological responses of European seabass Dicentrarchus labrax to different stocking densities and acute stress challenge. Aquaculture 275: 319-328.

Dural M., Genc E., Yemeniciolu S., Kemal Sangun M. 2010. Accumulation of some heavy metals seasonally in Hysterotylacium aduncum (Nematoda) and its host Red Sea Bream, Pagellus erythrinus (Sparidae) from Gulf of Iskenderun (North-Eastern Mediterranean). Bull. Environ. Contam. Toxicol. 84: 125-131.

EC 2001. Council Regulation (EC) No 2375/2001, 29 November 2001 amending Commission Regulation (EC) No 466/2001 setting maximum levels for certain contaminants in foodstuffs. Official Journal of the European Union.

EU 2004. Commision Directive 2004/44/EC of 13 April 2004 amending Directive 2002/69/EC laying down the sampling methods and the methods of analysis for the official control of dioxins and the determination of dioxin-like PCBs in foodstuffs. Official Journal of the European Union.

EC. 2006. European Commision Regulation 199/2006 ammending Regulation (EC) 466/2001 setting maximum levels for certain contaminants in foodstuffs as regards dioxins and dioxin-like PCBs. Official Journal of the European Union.

EC. 2007. Council Regulation (EC) No 834/2007, 28 June 2007. Organic production and labelling of organic products and repealing Regulation (EEC) No 2092/91. Official Journal of the European Union.

EC 2009. Commission Regulation (EC) No 710/2009, 5 August 2009 amending Regulation (EC) No 889/2008 laying down detailed rules for the implementation of Council Regulation (EC) No 834/2007, as regards laying down detailed rules on organic aquaculture animal and seaweed production. Official Journal of the European Union.

Ellis T., North B., Scott A.P., Bromage N.R., Porter M., Gadd D. 2002. The relationships between stocking density and welfare in farmed rainbow trout. J. Fish Biol. 61: 493-531.

European Food Safety Authority (ESFA) 2008. Scientific Opinion of the Panel on Animal Health and Welfare on a request from the European Commission on animal welfare aspects of husbandry systems for farmed European seabass and Gilthead seabream. The EFSA Journal 844: 1-21.

FishStatPlus 2008. FAO's Fisheries and Aquaculture Department. Statistical Collections. Capture production and Aquaculture production datasets 1950-206. ftp:ftp.fao.org/fishery/statistics/en/.

Froescheis O., Looser R., Cailliet G.M., Jarman W.M., Ballschmiter K. 2000. The deep-sea as a final global sink of semivolatile persistent organic pollutants? Part I: PCBs in surface and deep-sea dwelling fish of the North and South Atlantic and the Monterey Bay Canyon (California). Chemosphere 40: 651-660.

Gomez-Requeni P., Mingarro M., Kirchner S., Calduch-Giner J.A., Medale F., Corraze G., Panserat S., Martin S.A.M., Houlihan D.F., Kaushik S.J., Perez-Sanchez J. 2003. Effects of dietary amino acid profile on growth performance, key metabolic enzymes and somatotropic axis responsiveness of gilthead sea bream (Sparus aurata). Aquaculture 220: 749-767. 
Gram L., Huss H.H. 1996. Microbiological spoilage of fish and fish products. Int. J. Food Microbiol. 33: 121-137.

Grigorakis K. 2007. Compositional and organoleptic quality of farmed and wild gilthead sea bream (Sparus aurata) and sea bass (Dicentrarchus labrax) and factors affecting it: A review. Aquaculture 272: 55-75.

Kaiser M., Edwards-Jones G. 2006. The role of ecolabeling in fisheries management and conservation. Conserv. Biol. 20(2): 392-398.

Kaiser M., Hill L. 2010. Marine stewardship: a force for good. $\mathrm{Na}$ ture 467(7315): 531.

Kaushik S.J. 1998. Whole body amino acid composition of European sea bass (Dicentrarchus labrax), gilthead seabream (Sparus aurata) and turbot (Psetta maxima) with an estimation of their IAA requirement profiles. Aquat. Living. Resour. 11: 355-358.

Lem A. 2004. An overview of the present market and trade situation in the aquaculture sector - the current and potential role of organic products. FAO, Fishery Industries Division, HCM City.

Lie Ø., Lied E., Lambertsen G. 1986. Liver retention of fat and of fatty acids in cod (Gadus morhua) fed different oils. Aquaculture 59: 187-196.

Lundebye A.K., Berntssen M.H.G., Lie O., Ritchie G., Isosaari P., Kiviranta H., Vartiainen T. 2004. Dietary uptake of dioxins (PCDD/PCDFs) and dioxin-like PCBs in Atlantic salmon (Salmo salar). Aquac. Nutr. 10: 199-207.

Martinez F.J., Garcia-Riera M.P., Ganteras M., De Costa J., Zamora S. 1994. Blood parameters in rainbow trout (Oncorhynchus mykiss): Simultaneous influence of various factors. Comp. Biochem. Physiol. A. 107: 95-100.

Mendes R., Silva H.A., Nunes M.L., Empis J.M.A. 2005. Effect of low-dose irradiation and refrigeration on the microflora, sensory characteristics and biogenic amines of Atlantic horse mackerel (Trachurus trachurus). Eur. Food Res. Tech. 221: 329-335.

Mente E., Coutteau P., Houlihan D.F., Davidson I., Sorgeloos P. 2002. Protein turnover, amino acid profile and amino acid flux in juvenile shrimp Litopenaeus vannamei: effects of dietary protein source. J. Exp. Biol. 205: 3107-3122.

Mente E., Karalazos V. Karapanagiotidis I.T., Pita C. 2011. Nutrition in organic aquaculture: an inquiry and a discourse. Aquac. Nutr. 17(4): e798-e817.

Montero D., Izquierdo M.S., Tort L., Robaina L., Vergara J.M. 1999. High stocking density produces crowding stress altering some physiological and biochemical parameters in gilthead seabream, Sparus aurata, juveniles. Fish Physiol. Biochem. 20: 53-60.

Mozaffarian D., Rimm E.B. 2006. Fish intake, contaminants, and human health: Evaluating the risks and the benefits. J. Am. Med. Assoc. 296: 1885-1899.

Nácher-Mestre J., Serrano R. Benedito-Palos L., Navarro J.C., López F.J., Pérez-Sánchez J. 2009. Effects of fish oil replacement and re-feeding on the bioaccumulation of organochlorine compounds in gilthead sea bream (Sparus aurata L.) of market size. Chemosphere 76: 811-817.

Özyurt G., Polat A. 2006. Amino acid and fatty acid composition of wild sea bass (Dicentrarchus labrax): a seasonal differentiation. Eur. Food Res. Tech. 222: 316-320.

Papadopoulos A., Vassiliadou I., Costopoulou D., Papanicolaou C., Leondiadis L. 2004. Levels of dioxins and dioxin-like PCBs in food samples on the Greek market. Chemosphere 57: 413-419.

Papoutsoglou S.E., Tziha G., Vrettos X., Athanasiou A. 1998. Ef- fects of stocking density on behavior and growth rate of European seabass (Dicentrarchus labrax) juveniles reared in a closed circulated system. Aquac. Eng. 18: 135-144.

Pavlidis M.A., Mylonas C.C. 2011. Sparidae:Biology and aquaculture of gilthead sea bream and other species. Book. WileyBlackwell, Oxford, pp. 390.

Porter K.G., Feig Y.S. 1980. The use of DAPI for identifying and counting aquatic microflora. Limnol. Oceanogr. 25: 943-948.

Sanchez-Muros M.J., Corchete V., Suarez M.D., Cardenete G., Gomez-Milan E., de la Higuera M. 2003. Effect of feeding method and protein source on Sparus aurata feeding patterns. Aquaculture 224: 89-103.

Sará G. 2007. Ecological effects of aquaculture on living and non-living suspended fractions of the water column: A metaanalysis. Water Res. 41: 3187-3200.

Serrano R., Simal-Julian A., Pitarch E. 2003. Biomagnification study on organochlorine compounds in marine aquaculture: the sea bass (Dicentrarchus labrax) as a model. Environ. Sci. Tech. 37: 3375-3381.

Serrano R., Barreda M., Blanes M.A. 2008. Investigating the presence of organochlorine pesticides and polychlorinated biphenyls in wild and farmed gilthead sea bream (Sparus aurata) from the Western Mediterranean Sea. Mar. Pollut. Bull. 56: 963-972.

Simboura N., Catsiki V.A. 2009. The environmental impact of discharging metalliferous waste in a Mediterranean coastal area (Aegean Sea, N. Evvoikos gulf, Greece). In: McLaughlin N.Y., Breaux L.A. (eds.), Chemical Mineralogy, Smelting and Metallization. Nova Science Publishers, Inc. pp. 215-223.

Sitja-Bobadilla A., Pena-Llopis S., Gomez-Requeni P., Medale F., Kaushik S., Perez-Sanchez J. 2005. Effect of fishmeal replacement by plant protein sources on non-specific defence mechanisms and oxidative stress in gilthead seabream (Sparus aurata). Aquaculture 249: 387-400.

Storelli M.M., Perrone V.G., Marcotrigiano G.O. 2007. Organochlorine contamination (PCBs and DDTs) in deep-sea fish from the Mediterranean sea. Mar. Pollut. Bull. 54: 1968-1971.

Tacon A.G.J., Brister D. 2002. Organic aquaculture: Current standards and future prospects. In: Scialabba N.E.H., Hattam C. (eds.), Organic agriculture, environment and food security. Environment and Natural Resources Series No. 4. Food and Agriculture Organization of the United Nations (FAO), Rome, pp. 163-176.

Tacon A.G.J., Metian M. 2008. Global overview on the use of fish meal and fish oil in industrially compounded aquafeeds: trends and future prospects. Aquaculture 285: 146-158.

Teles A.O., Lupatsch I., Nengas I. 2011. Nutrition and feeding of Sparidae. Chapter 7. In: Pavlidis M., Mylonas C.C. (eds.), Sparidae: Biology and aquaculture of gilthead sea bream and other species. Wiley Blackwell, Oxford, pp. 199-223.

Terova G., Gornati R., Rimoldi S., Bernardini G., Saroglia M. 2005. Quantification of a glucocorticoid receptor in seabass (Dicentrarchus labrax, L.) reared at high stocking density. Gene 357: 144-151.

Turchini G.M., Torstensen B.E., Ng W.K. 2009 Fish oil replacement in finfish nutrition. Rev. Aquac. 1: 10-57.

Scient. ed.: S. Zanuy.

Received May 4, 2011. Accepted December 12, 2011.

Published online May 7, 2012. 